\title{
Strategic Planning Emphasis and Planning Satisfaction in Small Firms: An Emprircal Investigation
}

\author{
Javad Kargar \\ John A. Parnell \\ North Carolina Central University \\ Durham, NC
}

\begin{abstract}
Most empirical studies examining strategic planning effectiveness have focused on its impact on financial performance. However, solid empirically-based conclusions concerning the usefulness of strategic planning have not yet emerged. The present study takes an alternative perspective, examining two dimensions of executive satisfaction with strategic planning. Results support a link between seven strategic planning characteristics and planning satisfaction among small firms.
\end{abstract}

\section{Introduction}

According to a recent Business Week (1992:60) special edition, "change can [no longer] be an occasional episode in the life of a corporation. Companies with rigid structures will be swept away. Corporate cultures that can adapt will survive and thrive..." Flexibility-as well as the related constructs of speed, adaptability, and change - has been touted as a key tenet of the "paradigm for the postmodern manager" (Byrne, 1992:62). To yield positive results, change and flexibility necessitate prior effective strategic planning. However, researchers have not yet conclusively determined why some planning efforts are more successful than others in meeting this challenge.

The present study examines the relationship between various facets of strategic planning and performance in small community banks. Drawing on the planning literature, this article suggests that planning-performance research on small firms can produce meaningful results.

\section{Strategic Planning and Performance}

Over the past decade, researchers have investigated the effects of formal strategic planning on financial performance in small firms. Many have concluded that there is no consistent association between the strategic planning process and performance (Cappel, 1990; Greenley, 1986; Leontiades \& Tezel, 1980; Orpen, 1985; Robinson \& Pearce, 1983). In response to studies highlighting the impact of strategic planning on firm performance (Karger \& Malik, 1975; Rhyne, 1986; Sapp \& Seiler, 1981; Welch, 1984), recent research has 
seen a greater emphasis on the strategic process rather than only on the strategy content that Hofer (1975) proposed in his early study.

Steiner (1979) provided a thorough conceptualization of strategic planning. According to Steiner, planning is an attitude and a process concerned with the future consequences of current decisions. Formal strategic planning links short, intermediate, and long-range plans. Strategic planning does not attempt to make future decisions or even forecast future events. It need not replace managerial intuition and judgment with massive, detailed sets of plans.

Steiner argued for the importance of strategic planning, providing keen insight into overcoming the barriers and biases associated with planning failures. However, research by Steiner and others is founded in the critical assumption that planning is important. But the debate rages on in the literature. The key question remains: Is there really a link between planning and performance?

The literature is inundated with the apparent advantages of planning, most notably its ability to improve the fit between the organization and its external environment (Godiwalla, Meinhart, \& Warde, 1981). Others have argued that planning aids in the identification of future marketing threats and opportunities, elicits an objective view of managerial problems, creates a framework for internal communication, promotes forward thinking, and encourages a favorable attitude to change (Hausler, 1968; Loasby, 1967; Stern, 1966; Wilson, 1979). Further, there are intrinsic benefits that accrue as a result of the planning process, including the positive effects of planning on local employment and the economy (Greenley, 1986).

Langley (1988) also provided support for the benefits of planning, identifying four roles of formal strategic planning. In the public relations role, formal strategic planning is intended to impress or influence outsiders. The information role provides input for management decisions. The group therapy role is intended to increase organizational commitment through the involvement of people at all levels of the organization in strategic planning. Finally, the direction and control role is fulfilled when plans serve to guide future decisions and activities toward some consistent ends.

According to Roach and Allen (1983), the strategic planning process is the product of the best minds inside and outside the corporation. The process considers future implications of current decisions, adjusts plans to the emerging business environment, manages the business analytically, and links, directs, and controls complex enterprises through a practical, working management system. This process plays a vital role in firm performance (Roach \& Allen, 1983).

Cartwright (1987) suggested that effective planning is not as rational and analytical as it has been portrayed in the literature. He argues for the lost art (rather than science) of planning. He contends that planning is both (1) a generic activity whose success determinants are partially independent of the area in which it is applied, and (2) an area where judgment, intuition, and creativity are still important. 
Robinson and Pearce (1984) argued that formal strategic planning is a conceptual activity suited solely to larger firms and therefore has no effect on the financial performance of small firms. Wortman (1986) reviewed a set of small business planning-performance studies in the context of a broad survey of the methodologies employed in the small business literature. Wortman developed typologies but did not focus on the particular issue of the effect of formal strategic planning on small firm performance. However, he clearly addressed the need for continued refinement in planning-performance relationships and recommended the use of sophisticated statistical techniques for addressing such substantive research questions.

Greenley (1986) agreed with Robinson and Pearce and others to follow (Cartwright, 1987; Langley, 1988; Ramanujam \& Venkatraman, 1987), but provided an alternative perspective, suggesting that there may not even be a positive relationship between planning and performance. Specifically, Greenley noted the face validity of the planning-performance linkage, but reports that existing empirical data has not yet substantiated the relationship.

Ramanujam and Venkatraman (1987) provided limited support for Greenley's contention. However, their empirical analysis of high and low performing firms elicited significant differences between the groups that relate to the planning process. Specifically, their research examined the quality of the planning. For example, high performing firms tend to commit resources to planning and promote line-staff cooperation substantially more than low performing firms. Low performers may plan; they just may not plan effectively.

Pearce, Freeman, and Robinson (1987) examined the perceived substantive contributions of each of eighteen existing studies, concluding that empirical support for the normative suggestions that all small firms should engage in formal strategic planning has been inconsistent and often contradictory. In a similar vein, Schwenk and Shrader (1993) recently meta-analyzed fourteen studies on formal strategic planning and performance in small firms. While they did not find that planning necessarily improves performance, they argued against the assertion that strategic planning is only appropriate for large firms. As such, they concluded that strategic planning promotes long-range thinking, reduces the focus on operational details, and provides a structured means for identifying and evaluating strategic alternatives. Since this was the first review that clearly demonstrated the planning-performance link across studies, it strengthened the case for recommending the use of strategic planning in all firms, regardless of size.

Sinha (1990) appears to have empirically established some kind of a planning-performance linkage. Sinha examined 1087 decisions made by 129 Fortune 500 firms between 1982 and 1986. He concluded that characteristics of the decisions accounted for 15 percent of the variance in data and therefore should be regarded as important determinants of the contribution planning makes to decision making. However, Sinha concedes that the quality of planning is critical to the relationship. 


\section{Planning and Strategic Change}

There are three frequently cited reasons why top managers pursue changes in strategy (Parnell, 1994). First, a change in strategy may appear attractive because desired performance levels are not being attained by the organization. In many cases, top managers may believe that a change in strategy will improve the ability of the business to generate revenues or profits, increase market share, and/or improve return on assets or investment. Many studies have concluded that declining profitability is the most common catalyst for strategic change (Boeker, 1989; Webb \& Dawson, 1991).

Second, an environmental shift may necessitate strategic change to maintain alignment. Such shifts may result from changes in either the macroenvironment (e.g., new regulations, social forces, demographic changes, etc.) or the industry environment (e.g., new competitors, changes in competitor strategies, etc.). Changes in competition and technology necessitate a change in the knowledge base within the organization if it is to survive (Whipp, Rosenfeld, \& Pettigrew, 1989). According to the population ecology perspective (Hannan \& Freeman, 1977; Ulrich, 1987), the environment determines which organizations will survive and which ones will not. New firms better suited to the changing environment constantly replace existing ones. Competitors constantly struggle for existence by seeking to procure additional resources. As such, strategic change can be seen as a means to access additional resources and survive in a turbulent environment (Aldrich, McKelvey, \& Ulrich, 1984).

Third, strategic change can enhance effective resource utilization (Barney, 1991; Lado, Boyd, \& Wright, 1992). Proponents of the resource-based perspective have noted that competitive advantage often occurs from such organizational attributes as informational asymmetries (Barney, 1986b), culture (Barney, 1986a; Fiol, 1991), resource accumulation (Dierickx \& Cool, 1989), and the minimization of transaction costs (Camerer \& Vepsalainen, 1988). Hence, as organizational human and capital resources evolve, changes in strategy become necessary to fully utilize the resources available to the organization.

Resource shifts necessitating strategic change are more prevalent in some organizations than in others. Researchers have found that organizational performance, age, and length of tenure of the founding entrepreneur influence the degree to which a founding strategy endures and thus, the prospects for strategic change (Boeker, 1989). In fact, new CEOs are often recruited to attempt strategic changes upon entering the organization (Greiner \& Bhambri, 1989).

\section{Benefits and Costs of Strategic Change}

There are three potential benefits of strategic change that are commonly cited in the literature. First, strategic change can enhance the strategy-environment fit. For example, Calingo (1989) found that the low cost leadership strategy was most successful in price sensitive markets, whereas the differentia- 
tion strategy was most successful when consumers perceived great differences among product offerings.

Second, strategic change can open new dimensions of competitive advantage previously untapped by competitors. These first mover advantages result from the willingness of an organization to enter a new market or develop a new product or service prior to the competition (Gannon, Smith \& Grimm, 1992; Lieberman \& Montgomery, 1988; Mascarenhas, 1992; Wernerfelt \& Karnani, 1989).

Finally, strategic change can improve an organization's ability to adapt by forcing healthy changes within the business. The initial pain associated with change may be offset by the emergence of a lean, rejuvenated organization with a fresh focus on its goals and objectives. On the contrary, organizations that maintain strategic consistency over time may become stagnant, limiting the creativity and potential contributions of its members (Grimm \& Smith, 1991; Wiersema \& Bantel, 1992).

Regardless of the potential benefits, four potential costs that may be incurred as a result of strategic change have received considerable attention in the literature. First, strategic change increases perceived risks; a change in any key strategic, environmental, or organizational factor requires that the business develop a new "formula" for success suited to the change (Gaertner, 1989; Yoshihara, 1990). Second, change can disrupt the strategy-culture alignment (Green, 1988; Scholz, 1987; Schwartz \& Davis, 1981). Although the organizational culture may be changed (Saffold, 1988; Schein, 1990) to reflect and support the change in strategy, the period of time required to do so is likely to take several years (Lorenz, 1988; Saffold, 1988; Schein, 1985; Scholes, 1991). Third, measures required to implement a change in strategy may necessitate the outlays of capital (Miles \& Snow, 1978). Finally, strategic change may result in consumer confusion as they begin to alter their perceptions of the organization's products and services.

Even when strategic change results in a successful new product or service, there is no assurance that this success can be maintained. Indeed, competitors may distort consumer perceptions and reap the benefits of the initial strategic change. For example, many consumer goods companies implement an "imitation strategy" (Foxman, Muehling \& Berger, 1990). As a result, many consumers purchase the imitation product thinking it is the original. If the consumer dislikes the product, this dissatisfaction can be transferred to the original. If the consumer likes the product, the consumer may realize that the product is an imitator and transfer the positive associations with the original product to that of the imitator. Either scenario can prove costly to the originator (Loken, Ross \& Hinkle, 1986).

\section{Constructs and Propositions}

Empirical studies in small firms have generally employed a single dimension measure such as the presence or absence of planning or its degree of 
formality to explain variations in organizational performance. Such conceptualizations are inconsistent with the multidimensional view of planning systems that are being viewed as more important in the recent literature (e.g. Dyson \& Foster, 1982; King, 1983; Kukalis, 1991; Lorange, 1979, 1980; Rhyne, 1987; Veliyath \& Shortell, 1993).

Although many strategic planning system characteristics have been suggested in the literature, no consensus has yet emerged. For example, Ramanujam and Venkatraman (1987) proposed six dimensions of planning systems: use of techniques, attention to internal facets, attention to external facets, functional coverage, resources provided for planning, and resistance to planning. In another attempt to categorize strategic planning, Veliyath and Shortell (1993) identified five dimensions for strategic planning systems: planning implementation, market research competence, key personnel involvement, staff planning assistance, and innovativeness of strategies. Further, these studies focused on large firms. Thus, an expanded conceptualization of the notion of small-firm strategic planning is germane.

Following recent work (Ramanujam \& Venkatraman, 1987; Veliyath \& Shortell, 1993), the strategic planning system characteristics in the present study includes: (1) the degree of internal orientation of the system, (2) the degree of external orientation of the system, (3) the level of integration achieved within functional departments, (4) the extent of key personnel involvement in the planning process, and (5) the extent of use of analytical techniques in addressing strategic issues. These planning system attributes, in addition to being well-grounded in the existing literature (see Table 1), also appear to be problem areas in strategic planning within the banking industry.

\section{Two Dimensions of Planning Satisfaction}

Most researchers who have investigated small-firm strategic planning have used financial and marketing measures as indicators of performance. These performance measures are based on how a business has performed in the past, implicitly assuming that such success can be extrapolated into the future. However, financial superiority is only one element of organization performance. Perhaps more attention should be attached to an organization's ability to adapt to changes that are occurring and will occur in its environment. A realistic model of organization performance must reflect a highly complex paradigm and requires more than a single criterion (Brown \& Laverick, 1994). As such, the present study adopts a broader perspective, examining satisfaction with planning.

Specifically, two dimensions are examined: satisfaction with the concrete and financial outcomes believed to be associated with the planning process, and satisfaction with the contribution of strategic planning efforts to overall organizational effectiveness. The first dimension follows the tradition of earlier studies that sought to examine the impact of planning on financial performance. Although performance objectives were included in the goal attainment 
dimension, there is a clear distinction between achieving performance goals and being a high-performance organization. The second dimension reflects a goal-centered approach to assessing organizational effectiveness (Cameron \& Whetten, 1983; Ramanujam, Venkatraman \& Camillus, 1986). The goal attainment measure is primarily concerned with the specific end results normally anticipated from a planning system. This view reflects King's (1983) suggested approach to the evaluation of planning and Steiner's (1979) notion of measurement against purpose.

Table 1

Characteristics of Strategic Planning Systems

\begin{tabular}{l|l|l}
\hline Characteristic & Description & Supporting Literature \\
\hline $\begin{array}{l}\text { Internal } \\
\text { Orientation }\end{array}$ & $\begin{array}{l}\text { The extent of attention } \\
\text { devoted to an organization's } \\
\text { recent history and current } \\
\text { situation, past performance, } \\
\text { and analysis of strengths } \\
\text { and weaknesses }\end{array}$ & $\begin{array}{l}\text { Camillus \& Venkatraman (1984); } \\
\text { Cleland (1978); Lorange \& } \\
\text { Vancil (1977); Steiner (1979); } \\
\text { Stevenson (1976) }\end{array}$ \\
External & $\begin{array}{l}\text { Ability to obtain reliable and } \\
\text { timely research information } \\
\text { Orientation }\end{array}$ & $\begin{array}{l}\text { Andrews (1971); McDaniel \& } \\
\text { Kolari (1987); Ramanjam et al. } \\
\text { (1986); Snow \& Hrebiniak (1980); } \\
\text { Veliyath \& Shortell (1993) }\end{array}$ \\
Functional \\
Integration
\end{tabular}




\section{Propositions}

Almost all previous small-firm research has examined relationships between strategic planning and organization performance with unidimensional treatments. However, the issue becomes more complicated when both sets of variables are conceptualized in multidimensional terms, as some authors have recently argued (e.g. Ramanujam et al., 1986; Ramanujam \& Venkatraman, 1987). Hence, a positive relationship between strategic planning and performance dimensions among small firms is expected. Specifically, the present study posits two propositions:

1. Increased emphasis placed on each of the seven planning characteristics will be positively associated with each of the two dimensions of planning satisfaction.

2. Top executives of firms that place the greatest emphasis on all seven planning characteristics will report the greatest satisfaction with planning along the two dimensions. Likewise, top executives of firms that place the least emphasis on all seven planning characteristics will report the lowest satisfaction with planning along the two dimensions.

\section{Methodology, Analysis, and Findings}

\section{Sample}

Sixty-nine U.S. commercial banks in the state of North Carolina were examined, representing the entire population with fewer than $\$ 500$ million in total deposits. All 69 banks are considered small banks by banking industry standards (Robinson and Pearce, 1983).

Surveys were sent to the senior executives (presidents and/or CEOs) of all the 69 banks. To improve the response rate, the North Carolina Commissioner of Banks asked that each bank president and/or CEO cooperate by completing a questionnaire that would be sent to them. Forty-seven of the 69 banks completed and returned the research questionnaire for a response rate of 68 percent. Forty-one of these banks were chosen for further analysis to eliminate banks less than five years old as well as those that did not provide complete information. These criteria ensured that sample would not be biased toward banks with inadequately developed strategic planning systems, reducing the effective response rate to 59 percent.

North Carolina's small community banks provide an excellent opportunity to apply evaluation processes that are normally employed to study strategic planning in small businesses because they historically have had broad powers to engage in various businesses traditionally not associated with commercial lending (North Carolina Banking Commission, 1991). Challenges requiring strategic management by small community banks go beyond establishing new branches and typically include introducing new products/services, offering competitive personalized services, meeting the needs of small businesses, and altering racial lending patterns. The relative stability of the North Carolina com- 
mercial banks in an industry under turmoil also provided for a strong population from which to draw the sample. Further, there was only one bank failure each in 1991 and in 1993 in North Carolina.

\section{Strategic Planning Characteristics}

The specific strategic planning system characteristics are summarized in Table 2 and based on five-point Likert scales ranging from no emphasis (1) to great emphasis (5). Internal orientation was measured through the perceived degree of attention devoted to customer services, efficiency of operations process, attracting and retaining high-quality employees, and analysis of financial strengths and weaknesses. External orientation was measured by four items relating to the analysis of investment and deposit opportunities, competition and market analysis. Functional coverage was measured by Ramanujam and Venkatraman's (1987) four-item scale relating to the perceived degree of emphasis accorded to functional involvement, coordination, and integration in planning activity. Key personnel involvement was measured by the degree of CEO, board member, and line manager involvement in the strategic planning process. Creativity in planning is assessed by Ramanujam and others nine-item scale addressing the firm's ability to anticipate surprises and crises, to adapt to unanticipated changes, and so forth. The control aspect was measured by Ramanujam and others (1986) ten-item scale which addressed the degree of emphasis given to managerial motivation, upward and downward communication in the hierarchy, integration of operational areas, and the like. Finally, the use of planning techniques was measured by the degree of emphasis devoted to the application of financial models, portfolio analysis, and forecasting analysis techniques.

\section{Strategic Planning Satisfaction}

Planning satisfaction was measured via the two aforementioned dimensions, hereafter abbreviated as financial performance (FINANCE) and organizational effectiveness (ORGEFF). These dimensions were measured by an eight-item, two-factor scale (see Table 3) based on prior 'work by Ramanujam and Venkatraman (1987), including items addressing areas such as the prediction of future trends, improving short-term performance, improving long-term performance, evaluating alternatives, and enhancing management development. Respondents were asked to indicate their yiews via a 5-point scale, ranging from much deterioration (1) to much improvement (5), on eight criteria as a primary goal.

Factor loadings (see Tables 2 and 3 ) indicate that all the factors tapped characteristics measuring states of planning system and organization performance. Factor loadings in each scale were above 0.50 and eigenvalues for each factor were well above 1.0. Internal consistency of each scale was also assessed and judged strong using Cronbach's alpha (Cronbach, 1951; Van de Ven \& Ferry, 1980). These assessments provide adequate support for the reliability 
of the measures employed. Factor scores were computed for each planning system characteristic and planning satisfaction dimension to serve as composite measures for hypothesis testing.

Table 2

Planning System Characteristics and their Factor Loadings*

Internal Orientation (INTNLX 1: alpha $=\mathbf{0 . 7 9 )}$

Factor Loading

- Customer Services

0.57

- Efficiency of operating process

0.91

- Attracting and retaining high-quality employees

0.86

- Analysis of financial strengths and weakness

0.80

External orientation (EXTNLX1; alpha $=0.66$ )

- Analysis of investment opportunities

0.75

- Analysis of deposits opportunities

0.87

- Analysis of competition

0.73

- Performing market research

0.71

Functional coverage $($ FUNTNX1; alpha $=0.75$ )

- Marketing function

0.77

- Finance function

0.86

- Personnel function

0.77

- Operations function

0.72

Involvement of key personnel (RESRSX1; alpha $=0.51$ )

- Time spent by the CEO in strategic planning

- Involvement of line managers in strategic planning

0.54

- Involvement of board members in strategic planning

0.77

Use of planning techniques (TECHKX1; alpha $=0.63$ )

- Financial models

- Forecasting and trend analysis

0.86

- Portfolio analysis techniques

0.71

Creativity in Planning (CREATX1; alpha $=\mathbf{0 . 8 5}$ )

- Ability to anticipate surprises, threats and crises 0.74

- Flexibility to adapt to unanticipated changes $\quad 0.70$

- Value of a mechanism for identifying new business opportunities 0.53

- Role of identifying key problems 0.78

- Value as a basis for enhancing innovation $\quad 0.69$

- Capacity to generate new ideas 0.68

- Formulating goals to be achieved in the bank's competitive environment 0.50

- Capacity to generate and evaluate a number of strategic alternatives $\quad 0.72$

- Anticipating, avoiding, and removing barriers to strategy implementation 0.73

Focus on Control $($ CONTRX1; alpha $=0.94)$

- Value as a tool for management control

- Ability to communicate top management's expectations down the line 0.81

- Value as a tool for managerial motivation 0.79

- Capacity to foster organizational learning 0.78

- Ability to communicate line management's concern to top management 0.84

- Value as a mechanism for integrating diverse functions and operations 0.60 
Table 2

Planning System Characteristics and their Factor Loadings cont' $d^{*}$

- Monitoring \& controlling the implementation of the bank's strategy 0.90

- Using multiple financial \& non-financial control measures $\quad 0.83$

- Using control techniques for monitoring performance $\quad 0.89$

$\begin{array}{ll}\text { - Having control systems to revise current plans } & 0.83\end{array}$

*All scales were (1-5) Likert scales: no emphasis (1) to great emphasis (5)

Table 3

Satisfaction with Planning and their Factor Loadings

\begin{tabular}{lcc}
\hline & \multicolumn{2}{c}{ Factor Loadings } \\
Dependent Variables & FINANCE & ORGEFF \\
\hline Financial Performance Items: & & \\
$\quad$ Predictions of future trends & .73 & .41 \\
Enhancing management development & .59 & .37 \\
Improving short-term performance & .82 & .18 \\
Improving long-term performance & .84 & .15 \\
Direct impact on financial performance & .83 & .36 \\
Organizational Effectiveness Items: & & \\
Improving ability to evaluate alternatives & .15 & .85 \\
Improving ability to avoid mistakes & .27 & .79 \\
Improvement of budget process & .38 & .68 \\
\hline
\end{tabular}

*All scales were (1-5) Likert scales: no emphasis, to great emphasis.

Table 4 presents correlations among the dimensions. Each planning system characteristic positively and significantly correlates with only FINANCE and ORGEFF (at the .05 percent level). These results are consistent with the conceptual literature from which dimensions were distilled. The presence of the expected bivariate relationships between the planning system characteristics and these two satisfaction dimensions is encouraging, but the main focus of this study is on the multivariate relationship between the planning characteristics and planning satisfaction. Having established the existence of appropriate measurement scales, proposition testing can be pursued.

The first proposition was strongly supported. Emphasis on each of the seven planning characteristics was positively associated with both satisfaction dimensions. Further, firm size (EMPLOYES) was not significantly associated with any of the seven characteristics.

The second proposition was partially supported. To examine which factors contributed to the greatest satisfaction in planning along both dimensions, the forty-one businesses were clustered on the seven planning emphases into three distinct groups (see Table 5). The purpose of the cluster analysis was to identify several groups of organizations, each of which would contain businesses with similar emphases on the seven planning characteristics. Although 
Table 4: Descriptive Statistics and Correlations

\begin{tabular}{|c|c|c|c|c|c|c|c|c|c|c|}
\hline Correlations: & MPLOYES & INTNLX1 & EXTNLX1 & FUNTNX1 & RESRSX1 & TECHKX1 & CREATX1 & CONTRX1 & FINANCE & ORGEFF \\
\hline EMPLOYES & $\begin{array}{l}1.0000 \\
P=\end{array}$ & & & & & & & & & \\
\hline INTNLXI & $\begin{array}{c}.0041 \\
P=.490\end{array}$ & $\begin{array}{l}1.0000 \\
P=.\end{array}$ & & & & & & & & \\
\hline EXTNLX1 & $\begin{array}{l}-.1873 \\
P=.120\end{array}$ & $P=.000$ & $\begin{array}{l}1.000 \\
P=\end{array}$ & & & & & & & \\
\hline FUNTNX1 & $\begin{array}{l}-.1630 \\
P=.154\end{array}$ & $\begin{array}{r}.4739 \\
P=.001\end{array}$ & $\begin{array}{r}.7994 \\
P=.000\end{array}$ & $\begin{array}{l}1.0000 \\
P=.\end{array}$ & & & & & & \\
\hline RESRSX1 & $\begin{array}{r}.0914 \\
P=.285\end{array}$ & $P=.001$ & $\begin{array}{r}.3731 \\
P=.008\end{array}$ & $\begin{array}{r}.4411 \\
P=.002\end{array}$ & $\begin{array}{l}1.0000 \\
P=.\end{array}$ & & & & & \\
\hline TECHKX 1 & $\begin{array}{c}.1252 \\
\mathrm{P}=.218\end{array}$ & $\mathrm{P}=.018$ & $\begin{array}{r}.2641 \\
P=.048\end{array}$ & $\begin{array}{r}.3041 \\
P=.027\end{array}$ & $\begin{array}{r}.2812 \\
\mathrm{P}=.037\end{array}$ & $\begin{array}{l}1.0000 \\
P=\end{array}$ & & & & \\
\hline CREATX1 & $\begin{array}{l}-.2428 \\
P=.063\end{array}$ & $\begin{aligned} & .5637 \\
P & =.000\end{aligned}$ & $\begin{array}{c}.5416 \\
P=.000\end{array}$ & $\begin{array}{r}.4861 \\
P=.001\end{array}$ & $\begin{array}{r}.4654 \\
P=.001\end{array}$ & $\begin{array}{c}.5391 \\
\mathrm{P}=.000\end{array}$ & $\begin{array}{l}1.0000 \\
P=.\end{array}$ & & & \\
\hline CONTRX1 & $\begin{array}{l}-.1430 \\
\mathrm{P}=.186\end{array}$ & $\begin{aligned} .6026 \\
P=.000\end{aligned}$ & $\begin{array}{c}.5054 \\
\mathrm{P}=.000\end{array}$ & $\begin{array}{r}.4061 \\
P=.004\end{array}$ & $\begin{array}{r}.6053 \\
P=.000\end{array}$ & $\begin{array}{r}.5296 \\
\mathrm{P}=.000\end{array}$ & $\begin{array}{r}.8590 \\
P=.000\end{array}$ & $\begin{array}{l}1.0000 \\
P=.\end{array}$ & & \\
\hline FINANCE & $\begin{array}{l}-.2057 \\
P=.099\end{array}$ & $\begin{aligned} .3478 \\
\mathrm{P}=.013\end{aligned}$ & $\begin{array}{r}.4393 \\
P=.002\end{array}$ & $\begin{array}{r}.4872 \\
\mathrm{P}=.001\end{array}$ & $\begin{array}{r}.3529 \\
\mathrm{P}=.012\end{array}$ & $\begin{array}{c}.3952 \\
\mathrm{P}=.005\end{array}$ & $\begin{array}{r}.5863 \\
P=.000\end{array}$ & $\begin{array}{r}.5768 \\
P=.000\end{array}$ & $\begin{array}{l}1.0000 \\
P=.\end{array}$ & \\
\hline ORGEFF & $\begin{array}{l}-.0716 \\
\mathrm{P}=.328\end{array}$ & $\begin{aligned} & .3056 \\
P & =.026\end{aligned}$ & $\begin{array}{r}.3125 \\
\mathrm{P}=.023\end{array}$ & $\begin{array}{r}.2700 \\
\mathrm{P}=.044\end{array}$ & $\begin{array}{l}.3360 \\
P=.016\end{array}$ & $\begin{array}{r}.2702 \\
\mathrm{P}=.044\end{array}$ & $\begin{array}{c}.5901 \\
\mathrm{P}=.000\end{array}$ & $\begin{array}{r}.6272 \\
P=.000\end{array}$ & $\begin{array}{r}.0000 \\
\mathrm{P}=.500\end{array}$ & $\begin{array}{l}1.0000 \\
P=.\end{array}$ \\
\hline
\end{tabular}


a variety of clustering methods could be applied, Ward's algorithm was selected because of its tendency to cluster cases into groups of similar sizes, an aspect critical for small populations (Barney \& Hoskisson, 1990; Hair, Anderson \& Tatham, 1987). The optimum solution contained three clusters of eight, eleven, and twenty-two businesses.

Table 5

Planning System Satisfaction Means for each Cluster Cluster Analysis

\begin{tabular}{lcccc}
\hline Variable & $\begin{array}{c}\text { Cluster 1 } \\
(\mathrm{N}=8,19 \%)\end{array}$ & $\begin{array}{c}\text { Cluster 2 } \\
(\mathrm{N}=11,27 \%)\end{array}$ & $\begin{array}{c}\text { Cluster 3 } \\
(\mathrm{N}=22,54 \%)\end{array}$ & $\begin{array}{c}\text { Sig. } \\
\text { Level }\end{array}$ \\
\hline Employees & 235.38 & 592.64 & 118.68 & .178 \\
INTNLX1 & 0.37 & -0.32 & 0.02 & .335 \\
EXTNLX1 & 0.72 & 1.28 & 0.80 & .035 \\
FUNTNX1 & 0.87 & -0.53 & -0.05 & .006 \\
RESRSX1 & 0.43 & -0.20 & -0.06 & .375 \\
TECHKX1 & 0.38 & -0.12 & -0.08 & .500 \\
CREATX1 & 0.88 & -0.47 & -0.09 & .009 \\
CONTRX1 & 0.75 & -0.46 & -0.04 & .028 \\
FINANCE & 0.73 & -1.23 & 0.35 & .000 \\
ORGEFF & 1.09 & 0.39 & -0.59 & .000 \\
\hline
\end{tabular}

Firms in the first cluster placed the greatest emphasis on six of the seven planning characteristics and also reported the greatest satisfaction with planning along both dimensions. Firms in the second cluster placed the least emphasis on six of the seven characteristics, also reporting the least satisfaction with planning dimensions. Significant differences among the clusters were found in four of the seven emphases and both planning satisfaction dimensions. External emphasis did not associate with the other six planning characteristics, suggesting that heavy external emphasis may be more associated with planning that does not lead to satisfaction with the process.

\section{Conclusions and Future Directions}

Taken together, it seems evident that the relationship between planning and performance in small firms bears significantly on strategic management research and practice, and that strategy scholars should not abandon this line of inquiry altogether. The planning literature appears to suggest two key themes: First, planning should be an integral part of the strategic management process. The benefits of planning can outweigh the costs. And most critically, one's competitors will likely enjoy the benefits of planning. Therefore, to ignore planning is to relegate a source of competitive advantage to disadvantage.

The second theme is perhaps most critical. Effective planning-not just the process of planning-appears to be positively associated with performance. 
In other words, organizations that plan effectively are more likely to achieve higher performance than those that do not. But the key here is effective planning; Ineffective planning appears to have no predictable or consistent association with performance. Going through the motions of planning provides no great insights or benefits; it may actually result in a depletion of resources and lower quality decisions. Thus, a strong emphasis placed on planning is only justified when it is also focused on effective planning.

Future research may address five areas appropriate to this study. First, a longitudinal research design may improve the reliability of strategy measures and examine the long-term (i.e., beyond five years) effects of strategic planning. Golden (1992) found that 58 percent of organizations he surveyed did not agree with the previously validated accounts of their organization's past strategies! Hence, retrospective accounts of strategy and planning emphases may not always be valid. A longitudinal design would eliminate the reliance on CEOs' perceptions of past strategy - a limitation of this exploratory study.

Second, future inquiries should expand the planning assessment process beyond the chief executive officer. Although a high response may be more difficult when complete anonymity is not assured, a more accurate depiction of planning activity may be gleaned from surveying several managers within each organization in addition to the CEO. Further, the validation of self-reported financial results with archival data would improve the validity of the study.

Third, additional industries may be examined. This study addressed only the banking industry. Additional investigations should include those industries experiencing major macroenvironmental changes. In such industries, one may actually find a greater value in strategic planning activities.

Fourth, the identification of important planning characteristics should provide an impetus to further efforts at reconceptualizing planning in more realistic terms than the unidimensional treatments common in the previous smallfirm empirical research. Similarly, the results support such a multidimensional treatment, which argues against the use of narrow conceptualizations of planning effectiveness in future studies. In general, these findings suggest the need for future research to explore not only the degree of emphasis and perceived effectiveness of various strategic planning dimensions but also the reasons for these choices. Such research will help to provide a better understanding of why managers of small firms choose various strategic planning system approaches as well as how these approaches give rise to possible changes in organization strategy.

Finally, the present study involved a relatively small number of banks in the study. Future investigations into process and content dimensions unique to small firm strategic planning process could focus on larger industries. 


\section{References}

Aldrich, H., B. McKelvey, and D. Ulrich. "Design Strategy from the Population Perspective." Journal of Management 10 (1984): 67-86.

Andrews, K.R. The Concept of Corporate Strategy. Homewood, IL: Dow Jones-Irwin, 1971.

Barney, J.B. "Firm Resources and Sustained Competitive Advantage." Journal of Management 17 (1991): 99-120.

Barney, J.B. "Organizational Culture: Can it Be a Source of Sustained Competitive Advantage?" Academy of Management Review 11 (1986a): 656-665.

Barney, J.B. "Strategic Factor Markets: Expectations, Luck, and Business Strategy." Management Science 32 (1986b): 1231-1241.

Barney, J.B., and R.E. Hoskisson. "Strategic Groups: Untested Assertions and Research Proposals." Managerial and Decision Economics 11 (1990): 167-198.

Boeker, W. "Strategic Change: The Effects of Founding and History." Academy of Management Journal 32 (1989): 489-515.

Brown, D.M., and S. Laverick. "Measuring Corporate Performance." Long Range Planning 27 (1994); 89-98.

Business Week. "Managing Change." Business Week 1992 Special Bonus Issue: Reinventing America (1992): 60-74.

Byren, J.A. "Paradigms for Postmodern Managers." Business Week 1992 Special Bonus Issue: Reinventing America (1992): 62-63.

Calingo, L.M.R. "Environmental Determinants of Generic Competitive Strategies: Preliminary Evidence From Structured Content Analysis of Fortune and Business Week Articles (1983-1984)." Human Relations 42 (1989): 353-369.

Camerer, C., and A. Vepsalainen. "The Economic Efficiency of Corporate Culture." Strategic Management Journal 9 (1988): 115-126.

Cameron, K. and D.A. Whetten. Organizational Effectiveness: A Comparison of Multiple Models. New York: Academic Press, 1983.

Camillus, J.C. "Evaluating the Benefits of Formal Planning." Long Range Planning 8 (1975): $33-40$.

Camillus, J.C., and N. Venkatraman. "Dimensions of Strategic Choice." Planning Review 12 (1984): 26-31. 
Cappel, S.D. Strategic Profiles and Performance in Service Organizations: Examining Retail Department, Variety and General Merchandise Stores. Unpublished doctoral dissertation, Memphis State University, Memphis, Tennessee, 1990.

Cartwright, T.J. "The Lost Art of Planning." Long Range Planning 20 (1987): 92-99.

Cronbach, L.J. "Coefficient Alpha and the Intemal Structure of Tests." Psychometrica 16 (1951): 297-334.

Dierickx, 1., and K. Cool. "Asset Stock Accumulation and Sustainability of Competitive Advantage." Management Science 35 (1989): 1504-1511.

Dyson, R.G., and M.J. Foster. "The Relationship of Participation and Effectiveness in Strategic Planning." Strategic Management Journal 3 (1982): 77-88.

Fiol, C.M. "Managing Culture as a Competitive Resource: An Identity-Based View of Sustainable Competitive Advantage." Journal of Management 17 (1991): 191-211.

Foxman, E.R., D.D. Muehling, and P.W. Berger. "An Investigation of Factors Contributing to Consumer Brand Confusion." Joumal of Consumer Affairs 24 (1990): 170189.

Fredrickson, J.W. "The Comprehensiveness of Strategic Decision Process, Extensions, Observations, Future Directions." Academy of Management Journal 27 (1984): 45-466.

Gaertner, K.N. "Winning and Losing: Understanding Managers' Reactions to Strategic Change." Human Relations 42 (1989): 527-545.

Gannon, M.J., K.G. Smith, and C. Grimm. “An Organizational Information-Processing Profile of First Movers." Journal of Business Research 25 (1992): 231-241.

Godiwalla, Y.M., W.A. Meinhart, and W.A. Warde. "General Management and Corporate Strategy." Managerial Planning 30 (1981): 17-29.

Golden, B.R. "The Past is the Past-Or is it? The Use of Retrospective Accounts as Indicators of Past Strategy." Academy of Management Journal 35 (1992): 848-860.

Govindrajan, V. "Impact of Participation in the Budgetary Process on Managerial Attitudes and Performance: Universalistic and Contingency Perspectives." Decision Sciences 7 (1986): 96-516.

Grant, J.H., and W.R. King. The Logic of Strategic Planning. Boston: Little, Brown \& Company, 1982.

Green, S. "Strategy, Organizational Culture, and Symbolism." Long Range Planning 21 (1988): 121-129.

Greenley, G. "Does Strategic Planning Improve Company Performance?" Long Range Planning 19 (1986): 101-109. 
Greiner, L.E., and A. Bhambri. "New CEO Intervention and Dynamics of Deliberate Strategic Change." Strategic Management Journal 10 (1989, Summer): 67-86.

Grimm, C.M., and K.G. Smith. "Management and Organizational Change: A Note on the Railroad Industry." Strategic Management Journal 12 (1991): 557-562.

Hair, J.P., R.E. Anderson, and R.L. Tatham. Multivariate Data Analysis. New York: MacMillan, 1967.

Hannan, M. and J. Freeman. "The Population Ecology of Organizations." American Journal of Sociology 82 (1977): 929.964.

Hausler, J. "Planning: A Way of Shaping the Future." Management Intermational Review 2 (1968): 12-21.

Hax, A.C., and N.S. Majluf. Strategic Management: An Integrative Approach. Englewood Cliffs, NJ: Prentice-Hall, 1984.

Hitt, M.A., R.A. Ireland, and G.A. Stadter. "Functional Importance and Company Performance: Moderating Effects of Grand Strategy and Industry Type." Strategic Management Joumal 3 (1982): 315-330.

Hofer, C.W. "Toward a Contingency Theory of Business Strategy." Academy of Management Journal 18 (1975): 784-809.

Karger, D.W., and Z.A. Malik. "Long Range Planning and Organizational Performance." Long Range Planning 8 (1975): 60-64.

King, W.R. "Evaluating Strategic Planning Systems." Strategic Management Journal 4 (1983): $263-277$.

King, W.R., and D.I. Cleland. Strategic Planning and Policy. New York: Van Nostrand Reinhold, 1978.

Kukalis, S. "Determinants of Strategic Planning Systems in Large Organizations: A Contingency Approach." Journal of Management Studies 28 (1991): 143-60.

Lado, A., N. Boyd, and P. Wright. "A Competency Based Model of Sustained Competitive Advantage: Toward a Conceptual Integration." Journal of Management 18 (1992): 77-91.

Langley, A. "The Roles of Formal Strategic Planning." Long Range Planning 21 (1988): $40-50$.

Leontiades, M., and A. Tezel. "Planning Perceptions and Planning Results." Strategic Management Joumal 1 (1980): 65-75.

Lieberman, M.B., and D.B. Montgomery. "First-Mover Advantages." Strategic Management Joumal 9 (1988): 41-58. 
Loasby, B.J. "Long-Range Formal Planning in Perspective." Journal of Management Studies 4 (1967): 12-21.

Loken, B., I. Ross, and R.L. Hinkle. "Consumer Confusion of Origin and Brand Similarity Perceptions." Journal of Public Policy and Marketing 5 (1986): 195-211.

Lorange, P. "Formal Planning Systems: Their Role in Strategy Implementation." In Strategic Management: A New View of Business Policy and Planning. Eds. D.E. Schendel and C.W. Hofer. Boston: Little Brown \& Company, 1979.

Lorange, P. Corporate Planning: An Executive View Point. Englewood Cliffs, NJ: Prentice-Hall, 1980.

Lorange, P., and R.F. Vancil. Strategic Planning Systems. Englewood Cliffs, NJ: Prentice-Hall, 1977.

Lorenz, C. "Why Strategy has been Put in the Hands of Line Managers." Financial Times (May 18, 1988): 20.

Mascarenhas, B. "First Mover Effects in Multiple Dynamic Markets." Strategic Management Journal 13 (1992): 237-243.

McDaniel, S.W., and J.W. Kolari. "Marketing Strategy Implications of the Miles and Snow Strategic Typology." Journal of Marketing 51 (1987): 19-30.

Miles, R.E., and C.C. Snow. Organizational Strategy, Structure and Process. New York: West, 1978.

Mowday, R.T., L.W. Porter, and R.M. Steers. Employee-Organization Linkages - The Psychology of Commitment. Absenteeism and Turnover. New York: Academic Press, 1982.

North Carolina Banking Commission. State of North Carolina Commissioner of Banks 1991 Annual Report. Raleigh, NC: 1991.

Orpen, C. "The Effects of Long-Range Planning on Small Business Performance: A Further Examination." Joumal of Small Business Management 1 (1985): 16-23.

Parnell, J.A. "Strategic Consistency Versus Flexibility: Does Strategic Change Really Enhance Performance?" American Business Review 12 (1994): 22-30.

Pearce, J.A., II, E.B. Freeman, and R.B. Robinson. "The Tenuous Link Between Formal Strategic Planning and Financial Performance." Academy of Management Review 12 (1987): 658-675.

Ramanujam, V., and N. Venkatraman. "Planning and Performance: A New Look at an Old Question." Business Horizons 30 (1987): 19-25. 
Ramanujam, V., N. Venkatraman, and J.C. Camillus. "Multi-Objective Assessment of Effectiveness of Strategic Planning: A Discriminant Analysis Approach." Academy of Management Joumal 29 (1986): 347-372.

Rhyne, L.C. "Contrasting Planning Systems in High, Medium and Low Performance Companies." Joumal of Management Studies 24 (1987): 363-85.

Rhyne, L.C. "The Relationship of Strategic Planning to Financial Performance." Strategic Management Journal 7 (1986): 423-436.

Roach, J.D.C., and M.G. Allen. "Strengthening the Strategic Management Process." In The Strategic Management Handbook, 1983.

Robinson, R.B., and J.A. Pearce. "The Impact of Formalized Strategic Planning on Financial Performance in Small Organizations." Strategic Management Journal 4 (1983): 197-207.

Saffold, G.S. III. "Culture, Traits, Strength, and Organizational Performance: Moving Beyond Strong Culture." Academy of Management Review 13 (1988): 546-558.

Sapp, R.W., and R.E. Seiler. "The Relationship Between Long-Range Planning and Financial Performance of U.S. Commercial Banks." Management Planning 29 (1981): 3236.

Schein, E.H. "Organizational Culture." American Psychologist (Feb. 1990): 109-119.

Schein, E.H. Qrganizational Culture. San Francisco: Jossey-Bass, 1985.

Scholes, K. "The Way to Manage Strategic Change." Accountancy 107 (1991): 98-99.

Scholz, C. "Corporate Culture and Strategy-The Problem of Strategic Fit." Long Range Planning 20 (1987): 78-87.

Schwartz, H., and S. Davis. "Matching Corporate Culture and Business Strategy." Organizational Dynamics (Summer, 1981): 475-493.

Schwenk, C.R., and C.B. Shrader. "Effects of Formal Strategic Planning on Financial Performance in Small Firms: A Meta-Analysis." Entrepreneurship Theory and Practice 17 (1993): 53-64.

Shank, J.K., E.J. Niblock, and W.T. Sandall. "Balance 'Creativity' and 'Practicality' in Formal Planning." Harvard Business Review 51 (1973): 87-95.

Sinha, D.K. "The Contribution of Formal Planning to Decisions." Strategic Management Journal 11 (1990): 479-492.

Snow, C.C., and L. Hrebiniak. "Strategy, Distinctive Competence, and Organizational Performance." Administrative Science Quarterly 25 (1980): 317-35. 
Steers, R.M. "Antecedents and Outcomes of Organizational Commitment." Administrative Science Quarterly 22 (1977): 46-56.

Steiner, G.A. Strategic Planning: What Every Manager Must Know. New York: Free Press, 1979.

Stern, M.E. Marketing Planning: A Systems Approach. New York: McGraw-Hill, 1966.

Stevenson, H.H. "Defining Corporate Strengths and Weaknesses." Sloan Management Review 17 (1976): 51-68.

Ulrich, D. "The Population Perspective: Review, Critique, and Relevance." Human Relations 40 (1987): 137-152.

Van de Ven, A., and D. Ferry. Measuring and Assessing Organizations. New York: Wiley, 1980.

Veliyath, R., and S.M. Shortell. "Strategic Orientation, Strategic Planning System Characteristics and Performance." Journal of Management Studies 30 (1993): 359-381.

Webb, J., and P. Dawson. "Measure for Measure: Strategic Change in an Electronic Instruments Corporation." Journal of Management Studies 28 (1991): 191-206.

Welch, J.B. "Strategic Planning Could Improve Your Share Price." Long Range Planning 17 (1984): 144-147.

Wernerfelt, B., and A. Karnani. "Competitive Strategy under Uncertainty." $\underline{\text { Strategic }}$ Management Journal 8 (1987): 187-194.

Whipp, R., R. Rosenfeld, and A. Pettigrew. "Managing Strategic Change in a Mature Business." Long Range Planning 22 (1989): 92-99.

Wiersema, M.F., and K.A. Bantel. "Top Management Team Demography and Corporate Strategic Change." Academy of Management Journal 35 (1992): 91-121.

Wilson, R.M.S. Management Controls and Marketing Planning. London: Heinemann, 1979.

Wortman, M.S. "A Unified Framework, Research Typologies, and Research Prospectuses for the Interface between Entrepreneurship and Small Business." In The Art and Science of Entrepreneurship. Eds. D.L. Sexton and R.E. Smilor. Cambridge: Ballinger, 1986.

Yoshihara, H. "Originality in Management." Journal for Quality \& Participation (Dec. 1990): 14-21. 